\title{
Perbedaan Ekspresi Emosi pada orang Batak, Jawa, Melayu dan Minangkabau
}

\author{
Rina Suciati, Ivan Muhammad Agung \\ Fakultas Psikologi Universitas Islam Negeri Sultan Syarif Kasim Riau \\ email: ivan.agung@uin-suska.ac.id
}

\begin{abstract}
Abstrak
Ekpresi emosi merupakan salah satu penting dalam hubungan interpersonal manusia. Penelitian ini bertujuan untuk melihat perbedaan ekspresi emosi antara orang dari suku Batak, Jawa, Melayu dan Minangkabau. Jumlah subjek dalam penelitian ini adalah 413 orang. Subjek diambil dengan menggunakan teknik purposive sampling, yaitu subjek dipilih sesuai dengan karakteristik yang dibutuhkan dalam penelitian ini. Alat ukur dalam penelitian ini yaitu dengan menggunakan skala ekspresi emosi display rules assesment inventory (DRAI) yang dikembangkan oleh Matsumoto namun telah dimodifikasi sebelumnya oleh peneliti. Hasil analisis ANOVA pada penelitian ini menunjukan bahwa secara umum terdapat perbedaan yang signifikan dalam mengekspresikan emosi antara orang Batak, Jawa, Melayu dan Minangkabau ( $F=3,217$ dan $p=0,023)$. Berdasarkan hasil tersebut penelitian menyimpulkan bahwa display rules yakni standar-standar sosio-kultural yang mengatur kapan, dimana, dan bagaimana emosi-emosi diekspresikan mempengaruhi ekspresi emosi yang ditunjukan oleh individu pada masing-masing budaya.
\end{abstract}

Kata kunci: ekspresi emosi, orang Batak, Jawa, Melayu dan Minangkabau.

\section{The Difference of emotion expression on ethnic of Batak, Jawa, Melayu and Minangkabau}

\begin{abstract}
Expression of emotion is one of the important human interpersonal relationships. This study aims to look at the differences in the expression of emotions between people of Batak, Javanese, Malay and Minangkabau. The number of subjects in this study were 413 people. Subject was taken by using purposive sampling, that the subject chosen in accordance with the characteristics required in this study. Gauges in this research is by using a scale of emotional expression Display rules assesment inventory (DRAI) developed by Matsumoto and modified by researcher. Results of ANOVA analysis in this study shows that in general there are significant differences in expressing emotions among the Batak, Javanese, Malay and Minangkabau $(F=3.217$ and $p=0.023)$. Based on the results of the study concluded that the display rules the standards of socio-cultural set when, where, and how emotions are expressed to induce the expression of emotion shown by individuals in each culture.
\end{abstract}

Keywords: emotion expression, ethnic of Batak, Jawa, Melayu and Minangkabau

\section{Pendahuluan}

Universalitas ekspresi emosi telah banyak dibahas oleh beberapa tokoh terkemuka salah satunya adalah Ekman. Ekman (dalam Keltner \& Ekman, 2003) menemukan bahwa ada beberapa emosi yang pada dasarnya dimilliki dan diartikan sama oleh beberapa orang dari latar belakang lintas budaya yang berbeda-beda. Emosi yang universal tersebut adalah marah, muak, jijik, takut, bahagia, sedih, dan terkejut. Oleh karena itu, memahami ekspresi emosi antar lintas budaya menjadi salah satu hal penting dalam pergaulan kehidupan sehari-hari masyarakat majemuk. Terlebih, itu adalah ekspresi individual. Artinya melihat ekspresi pada diri individu itu sendiri. Menurut Keltner dan Ekman (2003) karena seorang individu yang dibesar- kan dalam kebudayaan tertentu akan memperoleh pengalaman dan memaknai suatu emosi yang ia pelajari misalnya dari proses labelling ekspresi wajah, suara, perilaku dan ucapan tertentu. Perbedaan atau variasi individu dalam mengekspresikan emosi yang tentu saja dipengaruhi oleh budaya dan adat istiadat. Ketika kemudian individu berbaur dengan masyarakat maka ekspresi emosi sepemahamannya akan muncul menjadi hasil (outcome) sosial.

Menurut Ekman (2003) secara biologis ekspresi emosi setiap budaya sama. Namun demikian budaya tetap memberikan pengaruh pada kapan, di mana dan bagaimana emosi diekspresikan (Display Rules). King (2010) berpendapat pentingnya display rules akan nyata ketika melakukan evaluasi terhadap ekspresi emosi orang lain. Menurut Mat- 
sumoto, dkk. (2008) perbedaan budaya mempengaruhi ekspresi emosi. Ekman (dalam Keltner \& Ekman, 2003) menemukan bahwa ada beberapa emosi yang pada dasarnya dimilliki dan diartikan sama oleh beberapa orang dari latar belakang lintas budaya yang berbeda-beda. Emosi yang universal tersebut adalah marah, muak, jijik, takut, bahagia, sedih, dan terkejut.

Penelitian tentang ekspresi emosi antar lintas budaya yang dilakukan oleh Safdar, dkk. (2009) sebagai contoh mencoba membandingkan ekspresi emosi antara orang Amerika (United State) dan Kanada yang individualis dengan orang Jepang yang kolektif. Hasilnya budaya individualis lebih terbuka dalam mengekspresikan emosi marah yang mereka rasakan dibandingkan dengan orang Jepang. Di Indonesia penelitian ekspresi emosi telah dilakukan dilakukan misalkan, oleh Handayani dan Nurwidawati (2013) tentang pola asuh dan eskpresi emosi keluarga dengan kekambuhan pasien shizoprenia Pada konteks budaya penelitian ekspresi emosi juga telah dilakukan Kurniawan dan Hasanat (2007) menjelaskan ekspresi emosi pada generasi pada budaya Jawa. Hasilnya menunjukan bahwa tidak terdapat perbedaan ekspresi emosi antar generasi pada suku Jawa di Yogyakarta. Generasi tersebut yaitu remaja (1821), dewasa awal (22-30) dan dewasa tengah (31-45). Ekspresi emosi yang ditunjukan oleh ketiga generasi tersebut pada dasarnya sama saja. Pada penelitian ini akan fokus ekspresi emosi pada lintas budaya (jawa, melayu, Batak dan Minangkabau) di Pekanbaru.

Masyarakat suku Minangkabau, Melayu, Jawa dan Batak merupakan masyarakat yang paling banyak tinggal di kota Pekanbaru. Data menunjukan persentase etnis yang ada di Pekanbaru (bappeda.pekanbaru.go.id) terdiri dari Melayu $(26,1 \%)$, Jawa $(15,1 \%)$, Minangkabau $(37,7 \%)$, Batak $(10,8 \%)$, Banjar $(0,2 \%)$, Bugis $(0,2 \%)$, Sunda $(1,0 \%)$, dan suku-suku lainnya. $(8,8 \%)$. Hal ini membuat orang-orang yang berasal dari keempat suku tersebut akan lebih sering bertemu, berinteraksi dan berkomunikasi di lingkungan sosial. Menurut Zubair (2012) ekspresi emosi merupakan bagian dari komunikasi nonverbal. Ekman (1997) menjelaskan bahwa ekspresi emosi akan sering terjadi selama seseorang berinteraksi dengan orang lain yang banyak dibangun oleh tindakan dibandingkan dengan yang lainnya. Selain itu ekspresi emosi berdasarkan pendapat Kurniawan dan Hasanat (2007) turut menentukan akan dikatakan baik atau buruk hubungan antarmanusia.

Matsumoto, dkk. (2008) menambahkan bahwa budaya mempengaruhi ekspresi emosi, karena dalam kebudayaan individu belajar untuk memilih reaksi emosional yang tepat ketika berhadapan dengan peristiwa dan tempat tertentu apakan itu di tempat pribadi atau di tempat umum. Matsumoto, dkk., (2005) juga mengatakan sebagai culture display rules, budaya memberikan pelajaran kepada masing-masing individu untuk menentukan bagaimana gaya dan cara mengekspresikan emosi yang tepat menurut budaya. Selain budaya, faktor konteks juga menentukan dalam ekspresi emosi. Faktor konteks dalam penelitian ini adalah tempat yaitu rumah sendiri dan di tempat umum.individu akan lebih ekpresif di rumah sendiri dibandingkan di tempat umum. Hal ini disebabkan karena di tempat umum ada aturan norma yang membatasi individu bagimana bersikap dan berperilaku di termpat umum.

Memahami karakter khususnya dalam berkomunikasi pada orang jawa, melayu, Batak dan Minangkabau merupakan suatu yang menarik. Setiap suku mempunyai ciri khas dalam berkomunikasi terutama dalam mengekspresikan emosinya. Suku Batak terkenal dengan keterbukaan, spontanitas dan keagresifannya baik secara fisik ataupun verbal. Penelitian yang dilakukan oleh Dewi (2005) mendukung pendapat tersebut, hasil penelitiannya menunjukan bahwa ketika marah orang Batak sering memilih untuk mengekspresikan rasa marahnya tersebut bila dibandingkan dengan orang Jawa yang cukup sering memilih memendam rasa marahnya. Wijayanti dan Nurwianti (2010) menjelaskan bahwa orang Jawa akan menerima apapun yang terjadi padanya tanpa ada upaya untuk menolak atau menghindar, suka atau tidak suka, mau atau tidak mau dan sangat berhati-hati dalam berbicara. Orang Jawa tidak terlalu ekspresif ketika mengekspresikan emosinya.Orang Batak terkenal dengan keterbukaan, spontanitas dan keagresifannya baik secara fisik ataupun verbal. Penelitian yang dilakukan oleh Dewi (2005) mendukung pendapat tersebut, hasil penelitiannya menunjukan bahwa ketika marah orang Batak sering memilih untuk mengekspresikan rasa marahnya. Hal ini turut membentuk stereotip bahwa orang Batak lebih cenderung ekspresif mengungkapkan emosinya.

Menurut Navis (1986) orang Minangkabau memiliki motivasi tinggi untuk hidup bersaing terus menerus dalam pencapaian kemuliaan, kepintaran dan kekayaan. Sehingga orang Minangkabau cenderung lebih berani dan terbuka.orang dari kebudayaan. Berbeda dengan orang Minang, menurut Harmaini (2011) orang Melayu memiliki ciri utama yaitu bersifat fungsional dalam mengakomodasi perbedaan-perbedaan. Kebudayaan Melayu mampu diterima oleh seluruh golongan masyarakat. Ekspresi emosi orang Melayu akan dipengaruhi oleh budaya Melayu yang lebih netral daripada bentuk ekspresi emosi 
antara budaya Jawa yang tidak ekspresif dengan budaya Batak dan Minangkabau yang lebih ekspresif.

Berdasarkan uraian tersebut maka hipotesis dalam penelitian:1) ada perbedaan ekspresi emosi antara suku batak, jawa, melayu dan minangkabau, dan 2) ada perbedaan ekspresi emosi ketika di rumah sendiri dan di tempat umum pada suku batak, jawa, melayu dan minangkabau

\section{Metode}

Subjek

Subjek penelitian berjumlah 413 orang, yang terdiri dari 102 orang bersuku Batak, 106 orang bersuku Jawa, 104 orang bersuku Melayu, dan 101 orang bersuku Minangkabau. Secara keseluruhan subjek dapat digambarkan berdasarkan jenis kelamin, subjek laki-laki berjumlah $179(43,3 \%)$ dan perempuan berjumlah 234 (56,7\%). Pemilihan subjek penelitian berdasarkan kriteria, yaitu 1) kedua orang tua sama-sama berasal dari suku bangsa yang sama, 2) pasangan hidup berasal dari suku bangsa yang sama (bagi yang sudah menikah) 3)Dapat berbicara dalam bahasa daerah suku bangsanya, 4) Merupakan anggota dari komunitas atau perhimpunan suku tertentu dari kelompok suku yang dimaksudkan (Batak, Jawa, Melayu dan Minangkabau). Teknik sampling menggunakan non probability sampling yaitu pengambilan sampel secara tidak acak. Pengambilan sampel dilakukan atas kriteria yang telah ditetapkan diawal.

\section{Pengukuran}

Skala yang digunakan dalam penelitian ini adalah skala modifikasi dari skala ekspresi emosi yang dikembangkan oleh Matsumoto (2005) yakni Display Rule Assesment Inventory (DRAI). Skala ekspresi emosi ini telah digunakan di Indonesia yaitu untuk mengukur perbedaan ekspresi emosi antar generasi di Yogyakarta oleh Kurniawan dan Hasanat (2007). Matsumoto (2005) menyusun skala ekspresi emosi ini untuk mengungkap bagaimana seseorang mengekspresikan 7 emosi pada dua situasi berbeda yaitu tempat pribadi (rumah sendiri) dan tempat umum dan pada 21 konteks interaksi yang berbeda. Namun pada penelitian ini peneliti hanya menggunakan satu saja konteks interaksinya yaitu ketika sedang "Sendiri" Hal ini dilakukan sesuai dengan karakteristik subjek penelitian yang dilihat secara umum. Penelitian lain yang juga melakukan hal yang sama yaitu menggunakan skala ini namun tidak kesemua konteks interaksinya adalah penelitian yang dilakukan oleh Kraft, dkk., (2012).Contoh aitem "Apakah yang anda yakini harus dilakukan jika anda merasakan emosi sebagai beri- kut (marah, muak, jijik, takut, bahagia, sedih dan terkejut). Saat itu anda sedang berada di tempat umum"

Menurut Matsumoto (2005; Matsumoto, dkk., 2005; Fok, dkk., 2007; Kurniawan \& Hasanat, 2007) terdapat enam pilihan kategori seseorang mengekspresikan ketujuh ekspresi emosi yang sudah universal yaitu marah, muak, jijik, takut, bahagia, sedih dan terkejut yakni:

1. Mengekspresikan emosi lebih dalam dari yang dirasakan tanpa ada upaya untuk menahan atau mengontrolnya (amplify) dengan skor 6

2. Mengekspresikan emosi seimbang dengan yang dirasakan (noinhibition) dengan skor 5

3. Tetap mengekspresikan emosi yang dirasakan namun disertai dengan senyuman (qualify) dengan skor 4

4. Mengekspresikan emosi kurang dari yang dirasakan (deamplify) dengan skor 3

5. Menyembunyikan perasaan yang dirasakan dengan senyuman (masking) dengan skor 2

6. Tidak mengekpresikan apapun (neutralise) dengan skor 1 .

Skor dimulai dari (6 - 1), artinya semakin tinggi jumlah skor yang dihasilkan maka dapat dikategorikan pula semakin ekspresif seseorang dalam pengekspresian emosinya. Sebaliknya semakin rendah jumlah skor yang dihasilkan maka semakin kurang ekspresif pula seseorang tersebut dalam pengekspresian emosinya.

Uji validitas dilakukan dengan sistem profesional judgement. Profesional judgement. Uji coba dilakukan dengan jumlah sampel 76 subjek yang terdiri dari orang Jawa, Batak, Melayu dan Minangkabau. Analisis uji coba menunjukan nilai koefisien korelasi masing-masing aitem skala ekspresi emosi. Nilai koefisien korelasi berkisar dari 0,264-0,537, dari hasil uji reliabilitas ini tidak ada satupun aitem yang gugur dalam uji coba penelitian ini. Uji reliabilitas dalam penelitian ini dilakukan dengan uji statistik SPSS 16 for windows. Yakni melalui analisis reliabilitas Cronbach's Alpha sebesar 0,799.

\section{Analisis Data}

Analisis data menggunakan teknik Independent T Test dan (Analysis Of Variances) ANOVA 1-jalur (one way anova) untuk mengetahui perbedaan ekspresi emosi pada kelompok suku Batak, Jawa, Melayu dan Minangkabau. Analisis data yang dilakukan dengan menggunakan program analisis data SPSS 16 for windows. 
Hasil

Hasil uji perbedaan ekspresi emosi antara suku Batak, Jawa, Melayu dan Minangkabau dengan menggunakan teknik anova 1-jalur menunjukan bahwa nilai $\mathrm{F}=$ $3,217, p=0,023(p<0,05)$. Artinya terdapat perbedaan ekspresi emosi antara suku Jawa, Batak, Melayu dan Minangkabau, dengan demikian hipotesis $(\mathrm{Ha})$ penelitian ini dapat diterima. Pada Tabel 1 menunjukan bahwa antara suku Batak dengan suku Jawa tidak menunjukan adanya perbedaan ekspresi emosi. $(p=$ $0,761)$. Antara suku Batak dengan suku Mel- ayu tidak adanya perbedaan ekspresi emosi $(p=0,234)$. Antara suku Batak dengan suku Minangkabau menunjukan tidak adanya perbedaan ekspresi emosi ( $p=0,717)$. Antara suku Jawa dengan suku Melayu menunjukan tidak adanya perbedaan ekspresi emosi $(p=0,792)$. Antara suku Jawa dengan suku Minangkabau tidak menunjukan adanya perbedaan ekspresi emosi $(p=0,174)$. Sementara itu antara suku Melayu dengan suku Minangkabau menunjukan adanya perbedaan ekspresi emosi $(p=0,018)$. Artinya perbedaan signifikan ditunjukan antara suku Melayu dan suku Minangkabau.

Tabel 1. Perbedaan ekspresi emosi berdasarkan suku

\begin{tabular}{|c|c|c|c|c|c|c|c|c|c|}
\hline \multirow[t]{2}{*}{ Suku } & \multirow[t]{2}{*}{$\mathbf{N}$} & \multirow{2}{*}{$\begin{array}{l}\text { Nilai } \\
\text { Rata-rata } \\
\text { (mean) }\end{array}$} & \multirow{2}{*}{$\begin{array}{l}\text { Simpangan } \\
\text { Baku (SD) }\end{array}$} & \multirow[t]{2}{*}{ Min } & \multirow[t]{2}{*}{ Maks } & \multicolumn{4}{|c|}{ p Value } \\
\hline & & & & & & Batak & Jawa & Melayu & Minang \\
\hline $\begin{array}{l}\text { Batak } \\
\text { Jawa } \\
\text { Melayu } \\
\text { Minang }\end{array}$ & $\begin{array}{l}102 \\
106 \\
104 \\
101\end{array}$ & $\begin{array}{l}52,33 \\
50,89 \\
49,53 \\
53,91\end{array}$ & $\begin{array}{l}11,123 \\
11,017 \\
10,95 \\
10,236\end{array}$ & $\begin{array}{l}26 \\
23 \\
27 \\
31\end{array}$ & $\begin{array}{l}76 \\
74 \\
73 \\
76\end{array}$ & & 0,761 & $\begin{array}{l}0,234 \\
0,792\end{array}$ & $\begin{array}{l}0,717 \\
0,174 \\
0,018^{*}\end{array}$ \\
\hline
\end{tabular}

Total 413

Catatan: * $p<0,05$

Tabel 2. Perbedaan ekspresi emosi berdasarkan tempat

\begin{tabular}{|c|c|c|c|c|c|c|}
\hline \multirow[t]{2}{*}{ Suku } & \multirow[t]{2}{*}{$\mathbf{N}$} & \multicolumn{2}{|c|}{ Di Rumah Sendiri } & \multicolumn{2}{|c|}{ Di Tempat Umum } & \multirow[t]{2}{*}{ p Value } \\
\hline & & Mean & SD & Mean & SD & \\
\hline $\begin{array}{l}\text { Batak } \\
\text { Jawa } \\
\text { Melayu } \\
\text { Minang }\end{array}$ & $\begin{array}{l}102 \\
106 \\
104 \\
101\end{array}$ & $\begin{array}{l}27,66 \\
26,6 \\
26,38 \\
28,24\end{array}$ & $\begin{array}{l}6,78 \\
6,897 \\
5,958 \\
6,331\end{array}$ & $\begin{array}{l}24,68 \\
24,28 \\
23,15 \\
25,67\end{array}$ & $\begin{array}{l}6,161 \\
5,848 \\
5,204 \\
5,8\end{array}$ & $\begin{array}{l}0,001^{* *} \\
0,009^{* *} \\
0,000^{* *} \\
0,003^{* *}\end{array}$ \\
\hline
\end{tabular}

Catatan: ${ }^{* *} p<0,01$

Tabel 2 menunjukan bahwa pada suku Batak, Jawa, Melayu dan Minangkabau terdapat perbedaan yang signifikan dalam mengekspresikan emosi antara ketika berada di rumah sendiri dan di tempat umum ( $p$ $<0,01)$, dengan demikian hipotesis 2 bahwa ada perbedaan ekspresi emosi antara di rumah sendiri dan di tempat umum pada suku
Batak, Jawa, Melayu dan Minangkabau dapat diterima. Suku Batak $(p=0,001)$, suku Jawa $(p=0,009)$, suku Melayu $(p=0,000)$ dan suku Minangkabau $(p=0,003)$ dan jika melihat dari nilai mean ketika berada di rumah sendiri baik suku Batak, Jawa, Melayu dan Minangkabau lebih ekspresif menunjukan emosinya dibandingkan dengan ketika di tempat umum.

Tabel 3. Perbedaan Ekspresi Emosi Berdasarkan Jenis Kelamin

\begin{tabular}{lllllll}
\hline \multirow{2}{*}{ Suku } & \multicolumn{3}{c}{ Di Rumah Sendiri } & \multicolumn{4}{c}{ Di Tempat Umum } \\
\cline { 2 - 3 } & \multicolumn{3}{c}{ Mean } & p value & \multicolumn{3}{c}{ Mean } & Pealue \\
\cline { 2 - 3 } & Laki-Laki & Perempuan & & Laki-Laki & Perempuan n & \\
\hline Batak & 27,40 & 27,9 & 0,71 & 24,96 & 24,4 & 0,651 \\
Jawa & 24,80 & 27,93 & $0,020^{*}$ & 23,67 & 24,74 & 0,354 \\
Melayu & 25,48 & 26,98 & 0,207 & 22,12 & 23,85 & 0,095 \\
Minang & 25,67 & 30,07 & $0,000^{* *}$ & 25,62 & 25,71 & 0,937 \\
\hline
\end{tabular}

Catatan: ${ }^{* *} \mathrm{P}<0,01{ }^{*} \mathrm{p}<0,05$ 
Tabel 4 menunjukan bahwa tidak terdapat perbedaan antara laki-laki dan perempuan suku Batak ketika di tempat umum dalam mengekspresikan emosinya $(\mathrm{p}=$ 0,651 ). Terdapat perbedaan terlihat antara laki-laki dan perempuan suku Jawa ketika di rumah sendiri dalam mengekspresikan emosinya $(p=0,020)$ dengan mean yang menunjukan bahwa pada suku Jawa ketika di rumah sendiri perempuan lebih ekspresif menunjukan emosinya dibandingkan dengan laki-laki. Di tempat umum tidak terdapat perbedaan antara laki-laki dan perempuan suku Jawa dalam mengekspresikan emosinya $(p=$
$0,354)$ Tidak terdapat perbedaan juga terlihat antara laki-laki dan perempuan suku Melayu ketika di rumah sendiri $(p=0,207)$ maupun di tempat umum $(p=0,095)$ dalam mengekspresikan emosinya.

Sementara itu pada suku Minangkabau terdapat perbedaan antara laki-laki dan perempuan suku Minangkabau ketika di rumah sendiri dalam mengekspresikan emosinya $(\operatorname{sig}=0,000)$ perempuan lebih ekspresif menunjukan emosinya dibandingkan dengan laki-laki ketika di rumah sendiri. Namum di tempat umum $(p=0,937)$ artinya tidak terdapat perbedaan.

Tabel 4. Perbedaan Ekspresi Emosi Berdasarkan Jenis Kelamin

\begin{tabular}{|c|c|c|c|c|}
\hline \multirow[t]{2}{*}{ Ekspresi Emosi } & \multicolumn{2}{|c|}{ Nilai Rata-rata (Mean) } & \multirow[t]{2}{*}{$\mathbf{F}$} & \multirow[t]{2}{*}{$p$ value } \\
\hline & $\begin{array}{l}\text { Laki-Laki } \\
(\mathrm{N}=179)\end{array}$ & $\begin{array}{l}\text { Perempuan } \\
(\mathrm{N}=234)\end{array}$ & & \\
\hline Marah & 8,24 & 7,83 & 1,292 & 0,79 \\
\hline Muak & 6,81 & 6,74 & 0,21 & 0,66 \\
\hline Jijik & 6,46 & 6,64 & 0,231 & 0,519 \\
\hline Takut & 6,45 & 7,73 & 0,616 & $0,000^{* *}$ \\
\hline Bahagia & 8,47 & 9,12 & 7,965 & $0,01^{*}$ \\
\hline Sedih & 5,85 & 6,82 & 0,571 & $0,000^{* *}$ \\
\hline Terkejut & 7,74 & 8,01 & 1,302 & 0,355 \\
\hline
\end{tabular}

Catatan: ${ }^{*} p<0,05^{* *} p<0,01$

Secara umum terdapat perbedaan ekspresi emosi antara laki-laki dan perempuan dengan nilai $F=0,195$ dan $p=0,007$. Perempuan $(M=52,89)$ lebih ekspresif dibandingkan dengan laki-laki $(M=50,01)$ Tabel 4 memperlihatkan analisis berikutnya terkait perbedaan ekspresi emosi berdasarkan jenis kelamin yaitu melihatnya pada masing-masing jenis emosi. Emosi marah diekspresikan dengan tidak berbeda oleh laki-laki dan perempuan $(F=1,292, p=0,79)$. Emosi muak juga diekspresikan dengan tidak berbeda oleh laki-laki dan perempuan $(F=0,21, p=0,66)$, laki-laki lebih ekspresif mengekspresikan muaknya dibandingkan dengan perempuan. Emosi jijik juga diekspresikan dengan tidak berbeda oleh laki-laki dan perempuan $(F=0,231, p=0,519)$, namun perempuan lebih ekspresif mengekspresikan jijiknya dibandingkan dengan lakilaki. Emosi takut diekspresikan berbeda oleh laki-laki dan perempuan $(F=0,616, p=0,000)$, perempuan lebih ekspresif mengekspresikan takutnya dibandingkan dengan laki-laki.

Emosi bahagia juga diekspresikan berbeda oleh laki-laki dan perempuan ( $F=7,965$, $p$ $=0,01$ ), perempuan lebih ekspresif mengekspresikan bahagianya dibandingkan dengan laki-laki. Emosi sedih diekspresikan berbeda oleh laki-laki dan perempuan $(F=0,571, p=$ 0,000 ), perempuan lebih ekspresif mengekspresikan sedihnya dibandingkan dengan laki-laki. Emosi terkejut diekspresikan dengan tidak berbeda oleh laki-laki dan perempuan $(F=1,302, p=0,355)$, namun perempuan lebih ekspresif mengekspresikan terkejutnya dibandingkan dengan laki-laki.

\section{Pembahasan}

Penelitian ini bertujuan untuk mengetahui perbedaan ekspresi emosi antara suku Batak, Jawa, Melayu dan Minangkabau yang tinggal di kota Pekanbaru. Perbedaan terlihat pada pengekspresian emosi antara suku Melayu dengan suku Minangkabau. Sementara antara suku Batak, Jawa dan Minangkabau masing-masing tidak memperlihatkan adanya perbedaan satu sama lain. Suku Minangkabau merupakan suku yang paling ekspresif menunjukan emosinya. Kemudian suku Batak, Jawa dan terakhir Melayu. Dilihat lebih spesifik dari konteks lingkungan, perbedaan antara suku Melayu dan Minangkabau tersebut terdapat ketika mengekspresikan emosi di tempat umum pada jenis emosi muak dan terkejut. Sementara itu, pada masing-masing suku terdapat perbedaan ekspresi emosi antara di rumah sendiri dan di tempat umum yaitu di rumah sendiri lebih ekspresif dibandingkan dengan di tempat umum.

Perbedaan ekspresi emosi ini disebabkan oleh adanya norma budaya pada 
masing-masing budaya yaitu Batak, Jawa, Melayu dan Minangkabau yang mengatur bagaimana individu dari masing-masing budaya tersebut harus selayaknya mengekspresikan emosi. King (2010) juga berpendapat bahwa cultural display rules yang merupakan standar sosio-kultural mengatur kapan, dimana dan bagaimana emosi-emosi diungkapkan. Senada dengan pendapat Ekman (1997), menurutnya display rules memanajemen seperti apa ekspresi emosi akan diungkapkan, apakah dengan pengurangan, melebih-lebihkan, seimbang atau mencakup tanda lainnya, serta terkait dengan kapan dalam situasi sosial.

Barrett dan Fussom (dalam Kurniawan \& Hasanat, 2007) menambahkan bahwa ekspresi emosi sebagai cermin dari pengaruh budaya dan sistem sosial. Berry (dalam Kurniawan \& Hasanat, 2007) juga mengatakan bahwa emosi tersebut dipelajari oleh individu sebagai nilai-nilai budaya dalam lingkungan sosial dimana ia tinggal. Sehingga setiap individu dari setiap budaya yang berbeda akan menunjukan ekspresi emosi yang berbeda pula sesuai dengan nilai budayanya. Baik suku Batak, Jawa, Melayu, ataupun Minangkabau sebagai suatu suku yang didalamnya berkembang nilai-nilai budaya yang mengatur tentang bagaimana emosi diekspresikan. Hal ini akan berbeda satu sama lain sehingga hasil penelitian juga menunjukan adanya perbedaan.

Peran culture display rules, yang menurut Ekman (1997), Matsumoto (2004), dan King (2010) merupakan standar sosiokultur yang mengatur atau mencocokan antara keadaan emosi dengan kapan, dimana, dan bagaimana emosi diekspresikan apakah dengan pengurangan, melebih-lebihkan atau seimbang. Standar sosio-kultural tersebut bisa jadi yaitu hubungan kekerabatan, kebersamaan dan kesatuan yang terjalin antara anggota keluarga satu sama lain yang membuat masing-masing merasa bahwa tidak perlu ada suatu hal yang ditutup-tutupi. Seperti yang dijelaskan oleh Prawitasari, Martani dan Adiyanti (dalam Hadiyono, 1999) bahwa bahkan jenis emosi tertentu seperti sedih dan takut sangatlah pribadi dan hanya orangorang tertentu saja (keluarga) yang boleh melihatnya,sehingga cukup beralasan bahwa saat mengeskpresi-kan emosi, ketika di rumah sendiri seseorang akan lebih ekspresif dibandingkan dengan di tempat umum.

Secara umum suku Minangkabau menjadi suku yang paling ekspresif mengekspresikan emosi-nya. Hal ini bisa jadi disebabkan oleh karena jumlah penduduk kota Pekanbaru yang mayoritas bersuku Minangkabau. Penduduk mayoritas menurut Koentjaraningrat (2004) biasanya lebih berani menunjukan eksistensinya pada lingkungan sekitarnya. Secara tidak langsung orang dari suku Minangkabau akan merasa dirinya lebih dominan dan lebih berani terbuka menunjukan ekspresi emosinya pada golongan minoritas.

Selain itu hal tersebut juga dapat dipengaruhi oleh falsafah orang Minangkabau yang dijelaskan oleh Navis (1986), menurutnya orang Minangkabau memiliki motivasi untuk maju yang tinggi, hal ini dikenal dengan istilah malawan dunia urang (melawan dunia orang). Motivasi ini diartikan sebagai amanat untuk hidup bersaing terus menerus dalam pencapaian kemuliaan, kepintaran dan kekayaan. Intinya adalah hidup bertujuan untuk memelihara harga diri supaya tidak kalah, rendah dan malu, selalu berlomba dan bersaing.

Suku Batak dalam meng-ekspresikan emosinya dapat dikatakan cukup ekspresif walaupun bukan yang paling ekspresif. Hal ini senada dengan hasil penelitian yang dilakukan oleh Dewi (2005), menurutnya orang dari suku Batak dikenal dengan kegigihannya, gaya bicara keras, berani dan bertindak tegas. Oleh karenanya orang Batak lebih suka berterus terang tentang emosi yang sedang dirasakannya. Hal tersebut pada dasarnya terbentukdari nilai-nilai budaya Batak yang sejak daluhu dianut dan disampaikan dari generasi ke genarasi yaitu dalihan na tolu.

Menurut Monika (2012) suku Batak dalam adat istiadatnya memakai suatu istilah yaitu dalihan na tolu. Dalihan na tolu mangatur bagaimana suku Batak bertingkah laku dalam kehidupan sosialnya. Istilah dalihan na tolu asal mulanya adalah tungku yang berkaki tiga. Tungku yang berkaki tiga tersebut dapat berdiri seimbang ditopang oleh tiga kakinya. Tungku berkaki tiga, jika satu kakinya rusak maka tungku tersebut tidak dapat digunakan karena tidak bisa seimbang. Kaitannya dengan ekspresi emosi adalah bahwa mengekspresikan emosi baik dalam bentuk tingkah laku, perkataan atau raut muka disesuaikan pula dengan kuat atau lemahnya emosi yang sedang dirasakan. Tidak melebih-lebihkan juga tidak berusaha menutup-nutupinya. Sehingga ekspresi emosi orang dari suku Batak tidak cenderung lemah atau disamarkan.

Suku Jawa kurang ekspresif menunjukan emosinya. Orang Jawa menurut Murwani (Wijayanti \& Nurwiati, 2010) terkenal dengan kepasrahan dan kesantunannya. Menurut Suseno (dalam Kurniawan \& Hasanat, 2007) prinsip hidup rukun, harmonis dan mengutamakan hubungan baik antar sesama pada orang Jawa mengakibatkan orang Jawa akan menghindari ekspresi emosi yang tidak terkendali.Menurut Geertz (1985) bagi orang Jawa setiap anggota keluarga somah merupakan suatu pribadi yang tunggal. Sikap 
terhadap keluarga sangat dipengaruhi oleh beberapa faktor yaitu: jenis kelamin, usia, posisi kelas, pandangan ideologi keagamaan, perasaan pribadi dan pertalian kekeluargaan. Sehingga masyarakat Jawa membatasi hubungan seseorang dengan orang lain dengan status kedudukan, usia, dan kekayaan. Pembatasan tersebut terutama dilihat dari faktor usia dan strata sosial pada penggunaan bahasa. Bahasa krama baik krama inggil, krama madya, maupun ngoko madya penggunaannya dalam kehidupan sehari-hari memerlukan basa, yaitu bahasa basa basi.

Oleh sebab itu orang Jawa tetap mengekspresikan emosinya namun kurang ekspresif karena dibatasi oleh stratifikasi bahasa komunikasi yang disesuaikan dengan siapa berkomunikasi. Hal serupa dengan hasil penelitian Dewi (2005), ini merupakan bentuk dari memberi hormat pada sesama, tenggang rasa dan ramah tamah untuk menghindari menyinggung perasaan orang lain dan cenderung mengontrol dengan ketat agar tidak ditunjukan berlebihan baik di rumah sendiri maupun dihadapan umum. Suseno (dalam Kurniawan \& Hasanat, 2007) berpendapat bahwa orang Jawa memiliki prinsip hidup rukun dan harmonis yang mengutamakan hubungan baik antar manusia, dengan demikian menunjukan emosi yang tidak terkendali, berkelahi terbuka akan sangat dihindari dan lebih memilih untuk memberi hormat pada sesama, gotong royong, tenggang rasa serta ramah tamah.

Suku Melayu paling tidak ekspresif menunjukan emosinya dibandingkan ketiga suku yang lain. Hal ini bisa jadi disebabkan nilai-nilai agama yang dianut budaya Melayu yang melarang suatu apapun dilakukan dengan berlebih-lebihan. Menurut Sarwono (2006) etnik Melayu dikenal dengan ketaatan beragamanya (Islam), lemah lembut, menyukai seni, serta tidak pernah melawan. Menurut Hamidy (1986) orang Melayu memiliki dua falsafah hidup yaitu, pertama orang Melayu merupakan satu etnis yang sederhana dalam penampilan dan gaya hidup. Sikap tidak ambisius dan kesederhanaan tindakan dan keinginann yang begitu dibatasi. Kedua, orang Melayu membuat orientasi hidup yang lebih horizontal bukan vertikal. Oleh sebab lebih diutamakan keharmonisan, ketentraman dan kebahagiaan dirinya dengan warga kiri, kanan dan lingkungan dibandingkan dengan pemimpinnya.Hamidy (1986) juga menambahkan bahwa emosi orang Melayu tidak begitu cepat akan berubah menjadi emosi agresi. Orang Melayu akan lebih memilih menghindar daripada melawan jika ada sesuatu yang tidak sesuai. Pemakaian katakata kiasan oleh orang Melayu dimaksudkan untuk menghindari kata-kata yang berterus terang dalam pergaulan sosial. Karena orang
Melayu percaya bahwa penyampaian yang berterus terang akan merendahkan martabat manusia itu sendiri. Hal ini dikenal dengan istilah metafor atau tersembunyi sebagai ciri sifat rendah diri orang Melayu.

Thamrin dan Iskandar (2009) menambahkan orang Melayu memiliki ciri-ciri kepribadian yang terbentuk tidak lepas dari tuntutan norma-norma adat istiadat yang terdapat dalam masyarakat Melayu (modal personality). Maka terbentuklah watak orang Melayu yaitu pertama sifat merendah diri yang ditunjukan dengan sikap tertib, sopan dan hormat. Kedua, sifat pemalu atau penyegan yaitu segan meminta tolong, segan menonjolkan diri, segan mengambil muka dan lainlain. Ketiga, sifat suka damai atau toleransi yang ditunjukan dengan mudah menjalin kerja sama, tidak cerewet atau banyak bicara. Keempat, sifat sederhana yaitu tenang, tidak tergesa-gesa, tidak tamak dan tidak serakah. Kelima, sifat sentimentil dan riang yakni menekan perasaan-perasaan dan gejolak sedih dan kembali riang gembira dengan tidak larut dalam kesedihan. Keenam, sifat mempertahankan diri biasanya bitunjukan dengan merajuk yakni menutup diri untuk membicarakan masalah yang menyebabkan perasaannya tersinggung. Kemudian merajuk dapat berkembang menjadi amuk yaitu sikap akhir yang diputuskan untuk membela harga diri yang telah dicemarkan oleh orang lain.

Watak orang Melayu mengantarkan pada ketika meng-ekspresikan emosi, orang Melayu akan cenderung menekannya supaya tidak begitu kuat diekspresikan karena hal tersebut bagian dari bentuk tidak ingin menonjolkan diri, suka damai dan toleransi. Bahasa lambang dan kias membuat komunikasi akan berjalan tanpa membangkitkan emosi negatif. Hal ini sesuai dengan salah satu bait gurindam 12 karya Raja Ali Haji yang berbunyi jika hendak mengenal orang yang berbangsa lihat kepada budi bahasa yang dipegang teguh oleh orang Melayu. Sementara,Suku Minangkabau dijelaskan oleh Navis (1986) juga memiliki budaya berpantun. Hanya saja tujuan dari pantun itulah yang membedakan pantun suku Melayu dan suku Minangkabau. Telah dijelaskan sebelumnya tujuan dari pantun dalan suku Melayu adalah untuk menghindari maksud-maksud yang berterus terang. Sementara pada suku Minangkabau tujuan berpantun dilakukan lebih kepada ketika menjajakan daganngan atau meratap dan berdendang. Sehingga suku Minangkabau tetap ekspresif atau berterus terang menunjukan emosinya.

Hal ini menunjukan bahwa benar secara khusus bahkan beberapa jenis emosi berdasarkan penilaian akan positif dan negatifnya harus ditekan pengeskpresiannya. Hadiyono (1999) menyatakan bahwa budaya 
kolektif lebih menekan emosi-emosi negatif untuk muncul dan lebih sering menunjukan emosi positif. Ekspresi emosi positif akan lebih dapat diterima daripada ekspresi emosi negatif. Suasana rasa negatif seseorang akan cenderung dinilai kurang mengenakkan bagi orang atau kelompok lain. Sama halnya dengan budaya Indonesia yang bersifat kolektif yang sering menunjukan ungkapan wajah yang positif dan gestur yang terkesan pasif agar mengurangi kesan negatif dari orang atau kelompok lain.

Begitu juga dengan Miyake dan Yamazaki (dalam Safdar, dkk., 2009) menurutnya ekspresi emosi negatif seperti ekspresi kemarahan kurang dapat diterima dalam budaya kolektif karena mengancam otoritas dan keharmonisan dalam hubungan. Termasuk juga ekspresi emosi penghinaan dan jijik yang tidak pantas diungkapkan secara terangterangan. Kitayama dan Markus (dalam Matsumoto, 2004) berpendapat bahwa emosiemosi negatif seperti marah, muak, dan sedih terjadi karena terhambatnya atribut internal seseorang seperti tujuan dan keinginan yang tidak terealisasikan atau diganggu. Budaya kolektif menurut Prawitasari (dalam Kurniawan \& Hasanat, 2007) selalu berusaha menempatkan segala sesuatu dalam keadaan seimbang atau cenderung tidak begitu ekspresif. Menurut Hadiyono (1999) terdapat dua cara mengekspresikan emosi yaitu secara verbal penuh kesadaran dan nonverbal, termasuk ekspresi wajah dari emosi yang berkaitan dengan hasil interpersonal dan sosial. Artinya ekspresi emosi berkaitan dengan penyampaiannya dalam dua bentuk tersebut yaitu secara verbal dan nonverbal. Hal ini mengantarkan pada penjelasan contex pengekspresian emosi.

Analisis berikutnya adalah peneliti membandingkan ekspresi emosi berdasarkan jenis kelamin. Secara umum perempuan lebih ekspresif menunjukan emosinya dibandingkan dengan laki-laki baik di rumah sendiri maupun di tempat umum.. Senada dengan temuan Fabes dan Martin (dalam Kraft, dkk., 2012), perempuan menunjukkan pengalaman emosinya dalam frekuensi yang lebih dan mempunyai kapasitas kontrol ekspresi emosi yang rendah. Jika dibandingkan dengan lakilaki yang menurut Jansz (dalam Kraft, dkk., 2012) bahwa laki-laki lebih akan menghambat ekspresi emosi mereka yang ia namakan dengan proses pembatasan emosi.

Hal ini senada dengan pendapat Markam (dalam Hadiyono, 1999) yang juga menemukan perbedaan makna positif dan negatif pada emosi antara laki-laki dan perempuan. Beberapa jenis emosi seperti terharu, sedih, cemas dan panik bagi perempuan dimaknai lebih positif yang merupakan sikap yang lebih optimis dan tidak dihindari sementara berbanding terbalik dengan lakilaki. Hal ini juga sesuai dengan hasil penelitian yang dilakukan oleh Kraft, dkk., (2012) bahwa perempuan lebih ekspresif menunjukan emosinya ketika sedang berinteraksi dengan rekan yang setara tingkatan dan dengan seseorang yang lebih rendah status sosialnya dibandingkan dengan laki-laki.

Menurut jenis emosinya, laki-laki lebih ekspresif mengekspresikan emosinya pada jenis emosi yang menunjukan kekuatan (emosi powerfull) yaitu marah dan muak dibandingkan dengan perempuan. Sementara perempuan lebih ekspresif mengekspresikan emosinya pada jenis emosi yang menunjukan ketidakberdayaan (emosi powerless) yaitu jijik, takut, sedih dan emosi positif yaitu bahagia dan terkejut. Hal ini senada dengan yang ditemukan oleh Safdar, dkk., (2009) dalam penelitiannya yang hasilnya menujukan bahwa perempuan lebih ekspresif menunjukan emosi powerless dan bahagia dibandingkan dengan laki-laki. Sementara laki-laki lebih ekspresif menunjukan emosi powerfull dibandingkan dengan perempuan. Hal ini bisa jadi disebabkan oleh perbedaan makna emosi positif dan negatif antara lakilaki dan perempuan yang juga dikemukakan oleh Markam (dalam Hadiyono, 1999) bahwa emosi terharu, sedih, cemas dan panik bagi perempuan dimaknai lebih positif yang merupakan sikap yang lebih optimis dan tidak dihindari, sementara tidak dengan laki-laki.

\section{Kesimpulan}

Ekpsresi emosi merupakan hal penting dalam kontegks interaksi manusia. Ekpresi emosi merupakan salah satu cara individu dalam berkomunikasi dengan orang lain. Ekspresi emosi ditentukan oleh faktor konteks dan budaya. Hasl penelitian penelitian menunjukkan bahwa secara umum terdapat perbedaan ekspresi emosi pada Batak, suku Jawa suku Minangkabau dan Melayu. Perbedaan khsusnya terjadi pada suku suku Minangkabau dan Melayu suku Minangkabau adalah suku yang paling ekspresif mengekspresikan emosinya, kemudian suku Batak, suku Jawa dan yang terakhir adalah suku Melayu. Sementara pada konteks lingkungan terdapat perbedaan ekspresi emosi antara di rumah sendiri dan di tempat umum. Perbedaannya adalah bahwa di rumah sendiri ekspresi emosi diekspresikan lebih ekspresif dibandingkan dengan di tempat umum. Berdasarkan jenis emosi, laki-laki lebih ekspresif meng-ekspresikan jenis emosi powerfull (kekuatan) yaitu marah dan muak dibandingkan dengan perempuan. Sementara perempuan lebih ekspresif mengekspresikan jenis emosi powerless (ketidakberdayaan) yaitu jijik, takut dan sedih serta emosi positif yaitu 
bahagia dan terkejut dibandingkan dengan laki-laki.

\section{Daftar Pustaka}

Andayani, Sari; Kouznetsova, Natalia; Krupp, Deborah; Matsumoto, David \& Takeuchi, Sachiko. (1998). The Contribution Of Individualism Vs. Collectivism To Cross-National Differences In Display Rules. Asian journal of social psychology 1: 147168

Cornelius, R. R. (2000). Theoretical Approaches To Emotion. Journal Vassar College Poughkeepsie, NY USA

Darwin, P., Hadisukanto, G., \& Elvira, D. Sylvia. (2013). Beban Perawatan dan Ekspresi Emosi pada Pramurawat Pasien Skizofrenia di Rumah Sakit Jiwa. Jurnal Indon Med Assoc, Volume: 63, Nomor: 2, Februari 2013

Dewi, L. Zahrasari. (2005). Pengalaman, Ekspresi, dan Kontrol Marah Pada orang Batak dan Jawa. Jurnal Psikologi Fakultas Psikologi UNIKA Atma Jaya Vol. 16, No. 2: Jakarta

Dewi, R., Innike \& Ermansyah.(2007). Badan Musyawarah Masyarakat Minang (BM3) (Studi Deskriptif Tentang Fungsi Organisasi Sosial Suku Bangsa Minangkabau di Kota Medan). Jurnal Departemen Sosiologi FISIP USU Medan

Ekman, Paul. (1997). Should We Call it Expression or Communication?. Innovations in Social Science Research, . 10, . 4,. 333-344,

Ekman, Paul. (2003). Darwin, Deception, and Facial Expression. Ann. N. Y. Acad. Sci. 1000: 205-221. New York Academy of Sciences. doi: 10.1196/ annals.1280.010

Ekman, Paul \& Friesen, V. Wallace. (2009). Buka Dulu Topengmu Panduan Membaca Emosi dari Ekspresi Wajah. BACA: Yogyakarta

Fok, H. K., Hui, C.M., Bond, M. H., Matsumoto, D., \& Yoo, S.H. (2007). Integrating personality, context, relationship, and emotion type into a model of display rules. Journal of research in personality 42 (2008) 133150

Geertz, Hildred.(1985). Keluarga Jawa. Grafiti Pers: Jakarta

Goleman, Daniel. (2004). Emotional Intelligence Kecerdasan Emosional Mengapa EQ Lebih Penting Daripada IQ. Gramedia Pustaka Utama: Jakarta

Hamidy, UU. (1986). Membaca Kehidupan Orang Melayu. Bumipustaka: Pekan- baru

Hamidy, UU.(1996). Orang Melayu di Riau. Pekanbaru: UIR Press

Harmaini. (2011). Psikologi Lintas Budaya. Almujtahadah Press: Pekanbaru

Handayani, L \& Nurwidawati, D. (2013). Hubungan Pola Asuh Dan Ekspresi Emosi Keluarga Dengan Kekambuhan Pasien Skizofrenia Di Rumah Sakit Jiwa Menur Surabaya. Jurnal Psikologi Teori \& Terapan 4, 1, 24 - 30

Hasbullah. (2009). Islam dan Tamadun Melayu. PekanBaru: Lembaga Penelitian dan Pengembangan fakultas Ushuludin UIN SUSKA Dan Yayasan Pustaka Riau

Hertinjung, S. W \& Partini. (2010). Gangguan Perilaku Pada Anak SD Ditinjau dari Ekspresi Emosi lbu

Jumlah Penduduk Pekanbaru Bertambah 71 Ribu Jiwa (on-line). Diunduh tanggal 11 Maret 2013. Dari http://bappeda. pekanbaru.go.id/berita/381/jumlahpenduduk-pekanbaru-bertambah71-ribu-jiwa/page/1/

Keltner, Dacher \& Ekman, Paul. (2003). Introduction:Expression Of Emotion. Handbook Of Afective Sciences. New York: Oxford University Press 411-414

King, A. Laura. (2010). Psikologi Umum Sebuah Pandangan Apresiatif Buku 2. Salemba Humanika: Jakarta

Koentjaraningrat. (2004). Manusia dan Kebudayaan di Indonesia. Djambatan: Jakarta

Koentjaraningrat. (2009). Pengantar IImu Antropologi. Rineka Cipta: Jakarta

Kottak, P. C.(2008). Cultural Anthropology. The McGraw-Hill Companies: US

Kraft, J. M., Lin, I. Y. Kwantes, C. T., Fernando, T., Samples, M., Thrasher, G., \& Woghiren, B. (2012). Journal Men and Women at Work: Emotional Display Norms in Organizational Settings. Presented at the 24th Annual Convention of the Association for Psychological Science, Chicago, USA.

Kurniawan, P. Aditya \& Hasanat, UI. Nida. (2007). Perbedaan Ekspresi Emosi Pada Beberapa Tingkat generasi Suku Jawa di Jogyakarta. Jurnal psikologi UGM Vol. 34 No. 1, 1 - 17.

Luthfi, Amir. (1986). Agama dan Interaksi Sosial Antar Kelompok Etnik: Studi Kasus Kotamadya Pekanbaru. Bumi Pustaka: Pekanbaru

Matsumoto, D. (2004). Pengantar Psikologi Lintas Budaya. Yogyakarta: Pustaka Pelajar

Matsumoto, D. (2005). Display Rules Assessment Inventory. (on-line). (C) David Matsumoto San Francisco 
State University

Matsumoto, D.; Yoo, H. S.; Hirayama, S. \& Petrova, G. (2005). Development and Validation of a Measure of Display Rule Knowledge: The Display Rule Assessment Inventory. Journal of Emotion by the American Psychological Association 2005, Vol. 5, No. 1, 23- 40

Matsumoto, D \& Ekman, P. (2007). Facial Expression Analysis. Journal of Paul Ekman Group LLC

Matsumoto, D; Yoo, H. Seung \& Fontaine, Johnny. (2008). Mapping Expressive Differences Around the World: The Relationship Between Emotional Display Rules and Individualism Versus Collectivism. Journal of Cross-Cultural Psychology 2008;39; 55.

Monika, H. Elizabeth. (2012). Budaya Patriarki Dan Perilaku Politik Perempuan dalam Pemilukada di desa Marsangap Tahun 2010. Jurnal Dinamika Politik| Vol.1| No.3| Desember 2012 ISSN: 2302-1470

Mulyana, D \& Rakhmat, J. (2001). Komunikasi Antarbudaya. Bandung: Remaja Rosdakarya

Navis, A.A. (1986). Alam Terkembang Jadi Guru Adat dan Kebudayaan Minangkabau. Grafitipers: Jakarta

Hadiyono, J.E. Prawitasari. (1999). Emosi dan Ekspresinya Dalam Masyarakat.
Buletin Psikologi. Yogyakarta: Fakultas Psikologi UGM Safa-

ria, Triantoro \& Saputra, E. Nofrans. (2009). Manajemen Emosi. Jakarta: Bumi Aksara

Safdar, S., Matsumoto, D., Kwantes, C.T., Friedlmeier, W., Yoo, S.H. \& Kakai, H. (2009). Variations of Emotional Display Rules Within and Across Cultures: A Comparison Between Canada, USA, and Japan. Canadian Journal of Behavioural Science Vol. 41, No. $1,1-10$

Sarwono, W. Sarlito. (2006). Psikologi Prasangka Orang Indonesia. PT. Raja Grafindo Persada: Jakarta

Thamrin, Husni \& Iskandar Koko. (2009). Orang Melayu Agama, Kekerabatan, Perilaku Ekonomi. SUSKA PRESS : Pekanbaru

Widodo, P. Budi. (2006). Konsep Diri Mahasiswa Jawa Pesisir dan Pedalaman. Jurnal Psikologi Universitas Diponegoro Vol. 3 No. 2, Desember 2006.

Wijayanti, He \& Nurwianti, F. (2010). Kekuatan Karakter dan Kebahagiaan pada Suku Jawa. Jurnal Psikologi Volume 3, No. 2, Juni 2010

Zubair, A.(2012). . . Komunikasi Non Verbal. Pusat Pengembangan Bahan AjarUMB (on-line)Diunduh tanggal 12 Desember 2012 dari kk.mercubuana. ac.id. 